\section{Coping with variability}

Wil Lepkowski reports on the response of US agriculture to climatic change, the subject of a recent report

THE one sure thing about the weather -and the climate-is that it will change. Therefore farmers, who depend on the weather, must be nimble. That is the essence of a report issued last month by the Washington-based Institute of Ecology under support from the Kettering Foundation of Dayton, Ohio. The report says climatoligists may not agree for some time over whether the climate is warming or cooling. But what they can agree on is that it will fluctuate. The strange point the report makes is that North American agriculture may be unprepared for the normal fluctuations in climate.

Why? It may have grown complacent over the good run of weather experienced during the 1950s and 1960 s, when agriculture boomed. As a result, the technology of fertilisation, pest control, and plant genetics may have softened crop resistance to fluctuation with the result that agriculture may have made itself vulnerable to trouble.

The panel, which had only six months to study the issue, makes three major recommendations: that weather scientists step up research on the processes and mechanisms of climatic change, that scientists develop research leading to improved strategies for food production under climatic stress, and that governments expand agricultural information networks to inform farmers more quickly of conditions affecting their crops.

The saga of the American farmer is that of a crusty realist always prepared for climatological vagaries. But this report emphasises agriculture's soft underbelly - that behind the legend lies bureaucratic complacency. It says with world population continuing to expand by 200,000 souls a day, and virtually all arable land under cultivation, agriculture is at the brink. It must be more watchful of its assumptions, more anticipatory of trouble. And the bureaucracy isn't.

The study, which was chaired by Professor James E. Newman, a Purdue University bioclimatologist, is ecology's first major try at tackling the agricultural policy issue. Its range was limited to Canadian wheat and American wheat, sorghum, corn, and soybeans, and it traced the production record of these crops under various degrees of climatological stress during the past 40 years. Its tone is that of a gentle warning rather than a vigorous call to action. One senses that farmers gathered for gossip at the general store would nod tired agreement but that the boardrooms of agribusiness corporations would pay only passing heed.

There is an undercurrent of concern over the vulnerability of technological agriculture, especially in view of its dependence on fossil fuel technology. And climate remains a concern. Four big studies are continuing in the US and each bears watching:

- "Study of Changing Climate Patterns and their Effect on Agricultural and Renewable Resource Productivity", by the National Academy of Sciences.

- "Living with Climatic Change", co-sponsored by the American Meteorological Society, the Canadian Meteorological Society, the Geophysical Institute of the National Autonomous University of Mexico, and the Science Council of Canada.

- The Large Crop Inventory experiment, by the National Aeronautics and Space Administration, US Department of Agriculture, and National Oceanographic and Atmospheric Administration

- "Impact of Climate Change on the Character and Quality of Human Life", by the Aspen Institute for Humanistic Studies.

\title{
BRITAIN
}

\section{Genetic manipulation: report due}

For many of Britain's molecular biologists, a long wait is almost over. Eleanor Lawrence reports

THE long-awaited report of the Williams Working Party on the Practice of Genetic Manipulation is "being printed and will be published shortly", according to $\mathrm{Mr}$ Fred Mulley, the UK Secretary of State for Education and Science, in a written reply to a Parliamentary question last week.

$\mathrm{Mr}$ Mulley was giving few details away on the code of practice itself, except that it will in the first instance be a voluntary one, with the possible introduction of specific statutory controls later in the light of experience. It will set out principles for categorising experiments and recommend various levels of safety precautions necessary for particular categories of experiment. But he shed a little light on the intended role of the proposed central advisory group. From this it looks as though scientists will have to wait until the advisory group is set up before their long-deferred experiments can begin.

The provision of a central advisory service for laboratories wishing to carry out genetic engineering was originally recommended by the Ashby Working Party which reported in January 1975. The experiments involve the transfer of alien genes to the common gut bacterium Escherichia coli by splicing the foreign genes onto a plasmid or bacteriophage vector.

One consequence of this might be that Escherichia coli with unusual and possibly harmful properties conferred on it by the transplanted genes might escape from the laboratory and infect the population at large. One of the fears when these experiments were first proposed was that they would be carried out in laboratories with little previous expenince of the microbiological techniques developed to contain potentiallv dangerous organisms.

The Williams Working Party has endorsed the idea of a central advisory service but apparently sees it as a watchdog as well as adviser. According to Mr Mulley's statement the Working Party has recommended that any laboratory contemplating experiments likely to come under the code should be required to notify the central advisory service before beginning work. This recommendation can be implemented through regulations which can be drawn up under the present Health and Safety at Work Act.

These recommendations will in some respects provide the proposed British scheme with an advantage over the recently-published American guidelines, which only strictly apply to work funded by the National Institutes of Health; in Britain, all laboratories, whether university, government or industrial, will be covered.

The Working Party report is expected within the month, and $\mathrm{Mr}$. Mulley intends to appoint the members of the central advisory group as quickly as possible and make immediate arrangements for it to get to work. The Health and Safety Commission will also soon be circulating for comment its proposals for regulations requiring notification of proposed experiments. 